Journal of Agriculture and Natural Resources (2019) 2(1): 60-74

ISSN: 2661-6270 (Print), ISSN: 2661-6289 (Online)

DOI: https://doi.org/10.3126/janr.v2i1.26043

Research Article

\title{
Diversity and occurrence of major diseases of vegetables and fruits during spring season at Aanbukhaireni rural municipality of Tanahun, Nepal
}

\author{
${ }^{1}$ Subash Subedi*, ${ }^{2}$ Sheela Koirala and ${ }^{1}$ Saraswati Neupane \\ ${ }^{1}$ Nepal Agricultural Research Council, National Maize Research Program Rampur, Chitwan, \\ Nepal \\ ${ }^{2}$ Nepal Polytechnic Institute (NPI), Purbanchal University, Bharatpur, Chitwan, Nepal \\ * Correspondence: subedi.subash1@gmail.com, ORCID: https://orcid.org/0000-0003-3739- \\ 1773
}

Received: August 18; Accepted: October 5; Published: October 25, 2019.

(C) Copyright: Subedi et al. (2019).

\section{(1) (3)}

International License.

\begin{abstract}
A survey has been conducted to assess the diversity and occurrence of major vegetables and fruits cultivated in Aanbukhaireni rural municipality of Tanahun district, Nepal during spring season of 2019.The surveyed areas were Satrasayaphant, Baradiphant and Dumridanda of ward no (WN) 1, Yeklephant, Markichowk and Pateni of (WN 2), Gaadapani of (WN 3), Saakhar of (WN 4) and Ghummaune of (WN 5). The surveyed area consists of upper tropical and sub tropical climate. The total no of farmers field selected were 34, 32, 24, 17 and 21 from ward no 1,2,3,4 and 5 respectively. The major vegetables cultivated were tomato, cucurbits, bean, brinjal, chilli, cowpea and okra while banana, papaya, mango, litchi, peach, guava, lemon and mandarin orange were the major fruits in the surveyed area. The major diseases of vegetables noticed were early and late blight, cercospora leaf spot, powdery mildew, downey mildew, fruit rot, bacterial wilt, bacterial spot, leaf curl and mosaic whereas sigatoka leaf spot, panama wilt, algal leaf spot, canker, root rot, sooty mold, red rust, anthracnose, rust, mosaic, and leaf curl were the major fruit diseases. The higher disease incidence (70\%) and severity (48\%) in vegetables were recorded in ward no 2 where as the lower incidence $(45.2 \%)$ and severity $(37.71 \%)$ were found in ward no 4. Similarly, the higher fruit disease incidence $(70.24 \%)$ and severity $(51.27 \%)$ in ward no 1 followed by ward no 2 with disease incidence and severity of $66.79 \%$ and $45.14 \%$ respectively. The reasons for those results are low educational level, lack of best bet technology, no proper irrigation and fertilizer, unavailability of pesticides for controlling the diseases. This study will be useful to identify the major diseases of vegetables and fruits of terai and inner terai region of Nepal and applying control measure, looking for the best possible solutions.
\end{abstract}

Keywords: Disease Incidence, Disease Severity, diversity, fruits, vegetables

Correct citation: Subedi, S., Koirala, S., \& Neupane, S. (2019). Diversity and occurrence of major diseases of vegetables and fruits during spring season at Aanbukhaireni rural municipality of Tanahun, Nepal . Journal of Agriculture and Natural Resources, 2(1), 60-74.

DOI: https://doi.org/10.3126/janr.v2i1.26043 
Journal of Agriculture and Natural Resources (2019) 2(1): 60-74

ISSN: 2661-6270 (Print), ISSN: 2661-6289 (Online)

DOI: https://doi.org/10.3126/janr.v2i1.26043

\section{INTRODUCTION}

Farmers in Nepal are known to grow a great richness of vegetable and fruit crops even at the household level, which is often attributed to different micro-environments of their fragmented land parcels, cultural importance and the social prestige too. Vegetables and fruits both are the cheapest and richest sources of calories, natural vitamins, minerals, dietary fiber and are therefore, named as "protected foods" which are essential to tackle the problems of malnutrition and improve quality of life (Choudhary et al., 2009). In Nepal, the total area under fruit production was 162660 ha with the productive area of 130449 ha and production $1058519 \mathrm{mt}$ and productivity $8.12 \mathrm{mt} / \mathrm{ha}$ (MOALD, 2018). Vegetables are grown in 286864 ha with the production of 3958230 mtand productivity of $13.79 \mathrm{t} / \mathrm{ha}$ in Nepal (MOALD, 2018). Pests and disease are destroying about one fifth of all crop production around the world and at least $10 \%$ of the global food production is lost through plant disease alone (FAO, 2000) mainly in West Africa and South Asia (Dhami et al., 2015). Diseases and pests are the major factors contributing to crop loss which hinders the income of rural families and global food security worldwide (Cerda, 2017). The resulting losses are, to a significant extent, the consequences of crops grown in monocultures and continuing evolution of new races of pests and pathogens that are able to overcome resistance genes introduced by modern breeding (Manandharet al., 2016). Local crop genetic diversity, and the associated indigenous knowledge is a tool for small-scale farmers in developing countries to meet their livelihood needs. The key factor to prevent the losses in the crop yield and quantity of agricultural products, proper identification and diagnosis of plant disease is utmost (Kumar \&Kaur, 2015). The use of a diversity of traditional crop varieties continues to be part of disease management strategy in genetically diverse systems for such farmers (Jarvis et al., 2011). Loss of local crops, which reduces the varietal choice, also reduces the farmers' capacity to cope with changes in pest and disease infestations, and leads to yield instability. Vegetables and fruit cultivation are one of the major economically important tool to contribute the livelihood of most of the farmers of Aanbukhaireni rural municipality of Tanahun district, Nepal. Diseases are the major limiting factors for the higher production of those commodities in this particular area which resulted great economic loss to the farmers. However, the potential disease pests of vegetables and fruit crops attacked their diversity and even occurrence and damage has not been systematically studied yet. The plant protection part has remained largely neglected from the research perspectives in Nepal. Farmers and researchers often do not report disease incidence or damage on fruit and vegetable crops in most part of the Nepal.Hence it is important to identify the major diseases of vegetables and fruits and applying control measure, looking for the best possible solutions. The main objective of this study is to survey of various diseases, their diversity, occurrence and intensity on vegetables and fruits cultivated in the farmersfields of Aanbukhaireni rural municipality of Tanahun district, Nepal.

\section{MATERIALS AND METHODS}

\section{Survey site}

Aanbukhaireni rural municipality is located at12 km north west from Mugling town on the Prithivi highway road on the bank of the Marshyangdiriver and covers an area of $67.3 \mathrm{~km}^{2}$ with 6 wards. It is the part of Tanahun districtinGandaki province in middlemost of country where Chitwan and Gorkha district lies in the east, Bandipur municipality and Devghat rural 
Journal of Agriculture and Natural Resources (2019) 2(1): 60-74

ISSN: 2661-6270 (Print), ISSN: 2661-6289 (Online)

DOI: https://doi.org/10.3126/janr.v2i1.26043

municipalitylies in the west, Bandipur municipality and Gorkha district in the north and Devghat rural municipality and Chitwan district in the south.The geographical location of the survey site is $27^{\circ} 89^{\prime} \mathrm{N}$ latitude and $84^{0} 51^{\prime} \mathrm{E}$ longitude at an altitude of 760 meters above seas level.Most of the surveyed areas are dominated by mid hills and plain. The climate is warm and temperate and fluctuating in the whole year inAanbukhaireni . When compared with winter, the summers have much more rainfall. The total annual average rainfall is about 2379 $\mathrm{mm}$ and the major amount of rainfall occurs between June and August. The average annual temperature varies from $6.5^{\circ}$ to $30.5^{\circ} \mathrm{C}$. The soil of the Aanbukhaireni is predominantly sandy loam followed by clay loam. The $\mathrm{pH}$ values for these soils are in the range of 5.5 up to 7.5 , suitable for vegetable and tropical fruit cultivation.

\section{Survey procedures and observations recording}

The survey has been conducted in spring season (March-May) of 2019 on vegetables and fruits crops grown in Aanbukhaireni rural municipality of Tanahun district, Nepal. The survey has been executed in farmers field of five wards i.e. Satrasayaphant, Baradiphant and Dumridanda villages of ward no 1, Yeklephant, Markichowk and Pateni villages of ward no 2 , Gaadapani village of ward no 3, Saakhar village of ward no 4 and Ghummaune village of ward no. 5. The surveyed area consists of upper tropical and sub tropical climate. The total no of farmers field selected for the survey was 34, 32, 24, 17 and 21 from ward no 1,2,3,4 and 5 respectively. The selected sites were approximately equal distance from each other along the sampling pathway. The major vegetables cultivated during survey period in the surveyed area were bean, bitter-gourd, brinjal, chilli, cowpea, cucumber, okra, pumpkin, sponge-gourd, tomato, snake-gourd and bottle-gourd. Similarly, the fruits found in the region were banana, papaya, grapes, mango, litchi, peach, guava, lemon, manadarin orange etc.For the surveillance, farmers, representatives from cooperatives, agricultural officers and technicians from line agencies and scientists from NARC Research stations were concerned. The disease data were recorded from 5 randomly tagged plants or branch $/ 1 \mathrm{~m}^{2}$ ploton the basis of $1-5$ scoring scale(Manandharet al., 2016).

1- No disease

2- Disease start or seen

3- Disease up to $25 \%$ part of the plant

4- Disease up to $50 \%$ part of the plant

5 - Disease more than $50 \%$ part of the plant

Based on the counts, disease incidence and index (severity) were recorded and suspected diseased specimens were collected for isolation and identification of pathogens under laboratory condition. Disease incidence was calculated based on the following formula.

$$
\text { Disease incidence }(\%)=\frac{\text { No. of infected plants }}{\text { Total no of plant assessed }} \times 100
$$

Percent Disease Index (PDI) was computed on the basis of recorded data according to the formula (Wheeler, 1969; Shrestha et al., 2019).

$$
\operatorname{PDI}(\%)=\frac{\text { Sum of all numerical values }}{\text { No of plants observed }} \times \frac{100}{\text { Maximum diseases rating }}
$$


Journal of Agriculture and Natural Resources (2019) 2(1): 60-74

ISSN: 2661-6270 (Print), ISSN: 2661-6289 (Online)

DOI: https://doi.org/10.3126/janr.v2i1.26043

A disease monitoring form was developed to record the surveyor name, location detail, date of the survey, latitude, longitude and elevation of the survey site, crop growth stage, soil type, soil texture, soil color, crop history, field area size, if disease sample collected (sample ID number) and finally any comments or observations like sex, age, occupation, education etc to understand the socio economic impact of the disease.

The data on meteorological factors, such as atmospheric temperature (maximum and manimum), relative humidity and rainfall during crop and survey period were recorded from the nearby meteorological stations installed at Bandipur and Damauli area.

\section{Isolation, identification and confirmation of the pathogen}

Infected plant samples of leaves, fruits and twigs have been collected in paper packets and brought to laboratory of National Maize Research Program (NMRP), Rampur, Chitwan for identification of pathogens. All materials which are used in this experiment were sterilized using ethyl alcohol except the samples. The diseased parts were cut into small pieces of 1-2 $\mathrm{cm}$ with some healthy part. The small pieces were washed with tap water and surface sterilized with $10 \% \mathrm{NaOCl}$ for 30 to $60 \mathrm{sec}$, again rinsed with sterile water and blotted to dry on clean tissue paper. After drying, three pieces were aseptically placed into Petri dishes containing Potato Dextrose Agar (PDA) medium. Then, the inoculated Petri dishes have been marked with name of the sample and date of inoculation and incubated at a temperature of $25^{\circ} \mathrm{C}$ for 5 days, until pathogen proliferation on medium surface. Fungal identifications were carried out on the basis of characterization of colonies and have also been examined under a compound microscope with 40X magnification (Aneja, 2004).

\section{Data analysis}

All data were analyzed statistically using Microsoft Excel (2007) computer package program. The average mean, standard deviation and standard error was calculated. Disease maps were developed by using ArcGIS 10.3 software.

\section{RESULTS AND DISCUSSION}

\section{Surveyed map and meteorological observations}

The vegetable and fruit disease status of surveyed areas is shown in the map (Figure 1). The weather data related to crop and survey period is shown in the figure 2 . The average maximum temperature ranges from 19.3 to $30.44^{\circ} \mathrm{C}$, average minimum temperature ranges from 6.16 to $19.75^{\circ} \mathrm{C}$. The total annual rainfall during crop period was $1037.2 \mathrm{~mm}$ and average relative humidity ranges from $78.69 \%$ (Figure 2 ).

Climatic factors play major role for the production of most of the vegetables and fruits worldwide. Moreover, increasing temperatures, reduced irrigation-water availability, flooding, and salinity will be the major limiting factors in sustaining and increasing vegetable and fruit productivity (Abewoy, 2018). 
Journal of Agriculture and Natural Resources (2019) 2(1): 60-74

ISSN: 2661-6270 (Print), ISSN: 2661-6289 (Online)

DOI: https://doi.org/10.3126/janr.v2i1.26043

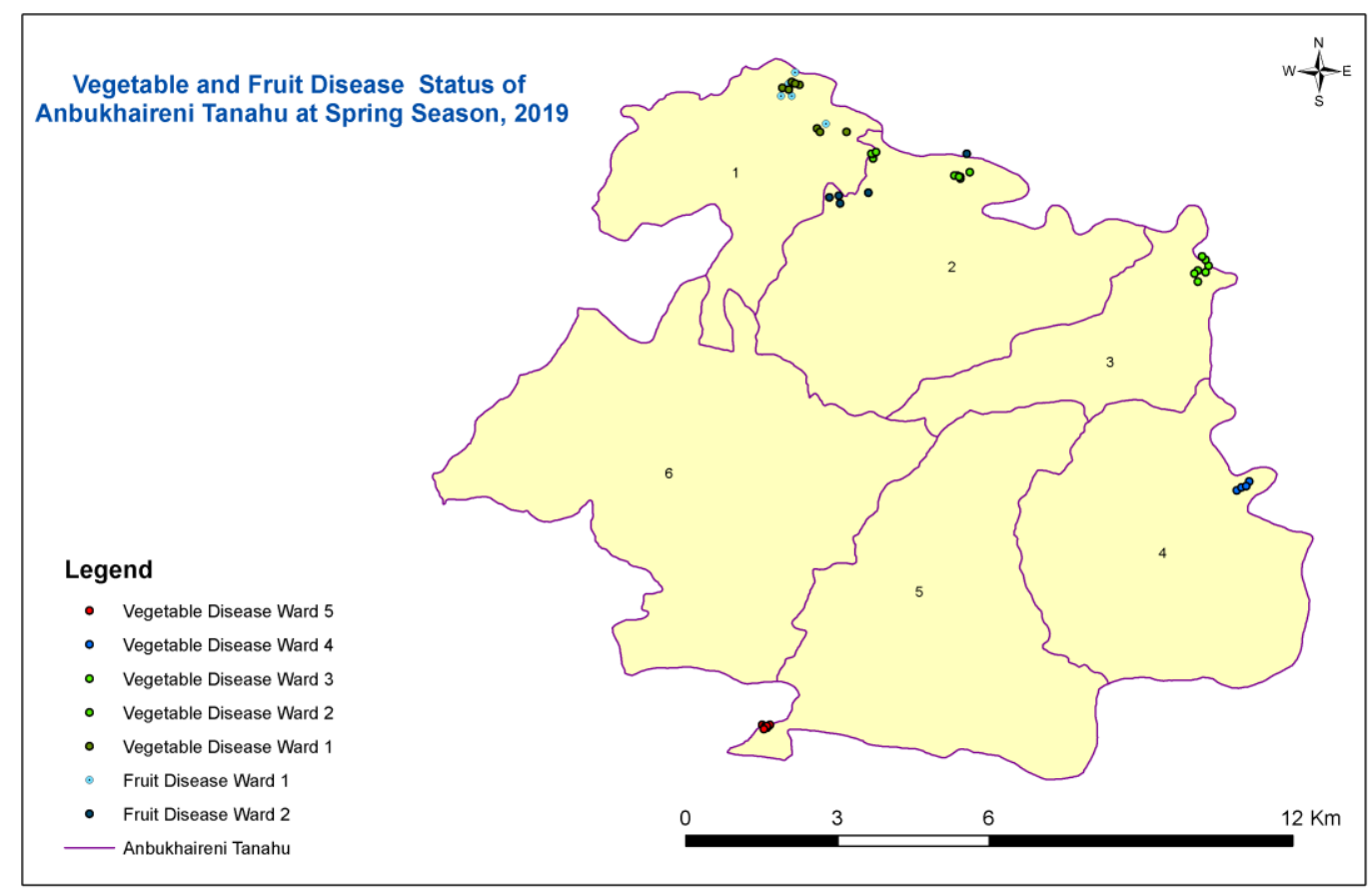

Figure 1: A map showing vegetable and fruit disease status of Aanbukhaireni, Tanahun of Nepal during spring season 2019

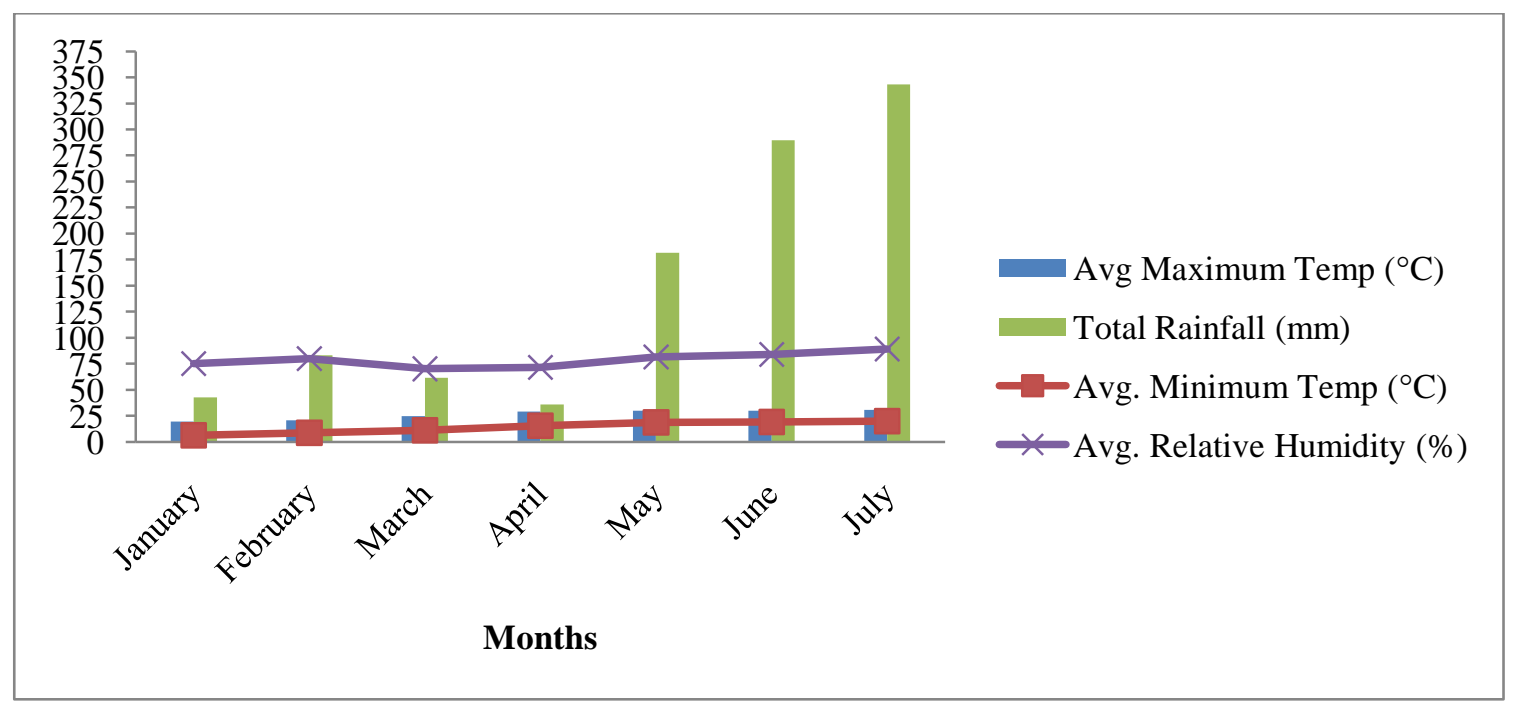

Figure 2:The data on meteorological factors, as atmospheric temperature (maximum and minimum), relative humidity and rainfall of Aanbukhaireni, Tanahun of Nepal during crop and survey period 2019.

Climate change influence the pest and disease occurrences, host-pathogen interactions, distribution and ecology of pests, time of appearance, migration to new places and their overwintering capacity, there by becoming major setback to vegetable and fruit cultivation. Excessive soil moisture due to heavy rain becomes major problem that can be overcome by growing crops on raised beds. Development of genotypes tolerant to high temperature, moisture stress, salinity and climate proofing through conventional, non-conventional, breeding techniques, genomics and biotechnology etc. are essentially required to meet these 
Journal of Agriculture and Natural Resources (2019) 2(1): 60-74

ISSN: 2661-6270 (Print), ISSN: 2661-6289 (Online)

DOI: https://doi.org/10.3126/janr.v2i1.26043

challenges (Abewoy, 2018). The changing patterns of climatic parameters like rise in atmospheric temperature, changes in precipitation patterns, excess UV radiation and higher incidence of extreme weather events like droughts and floods are emerging major threats for vegetable and fruit production in the tropical zone (Tirado et al., 2010) . Vegetable and fruit crops are very sensitive to climatic vagaries and sudden rise in temperature as well as irregular precipitation at any phase of crop growth can affect the normal growth, flowering, pollination, fruit development and subsequently decrease the crop yield (Afrozaet al., 2010).

\section{Diseases of vegetables}

The major vegetables cultivated during survey period in the surveyed area were bean, bittergourd, brinjal, chilli, cowpea, cucumber, okra, pumpkin, sponge-gourd, tomato, snake-gourd and bottle-gourd. The major diseases of vegetables cultivated in farmer's field of 5 wards of Aanbukhaireni rural municipality were early blight, late blight, cercospora leaf spot, powdery mildew, downey mildew, fruit rot, bacterial wilt, bacterial spot, leaf curl and mosaic (Table 1, Plate 1).

Table 1: Major diseases on vegetables cultivated in farmers field of 5 wards of Aanbukhaireni rural municipality of Tanahun district, Nepal during spring season of 2019

\begin{tabular}{|c|c|c|c|c|}
\hline Ward no $1(n=15)$ & Ward no $2(n=18)$ & $\begin{array}{l}\text { Ward no } 3 \\
(n=21)\end{array}$ & $\begin{array}{l}\text { Ward no } 4 \\
(n=14)\end{array}$ & Ward no $5(n=19)$ \\
\hline $\begin{array}{l}\text { Bacterial brown spot of } \\
\text { Bean }^{B}\end{array}$ & $\begin{array}{l}\text { Bacterial brown } \\
\text { spot of Bean }{ }^{B}\end{array}$ & $\begin{array}{l}\text { Mosaic of } \\
\text { Brinjal }^{\mathrm{V}}\end{array}$ & $\begin{array}{l}\text { Cercospora leaf } \\
\text { spot of Chili }\end{array}$ & $\begin{array}{l}\text { Cercospora leaf } \\
\text { spot and } \\
\text { Phomopsis blight } \\
\text { of Brinjal }^{\mathrm{F}}\end{array}$ \\
\hline Anthracnose of Bean ${ }^{F}$ & Leaf curl of Bean ${ }^{\mathrm{V}}$ & $\begin{array}{l}\text { Bacterial leaf } \\
\text { spot of Chili }{ }^{B}\end{array}$ & $\begin{array}{l}\text { Leaf curl and } \\
\text { Mosaic of Chili } \\
\text { V }\end{array}$ & 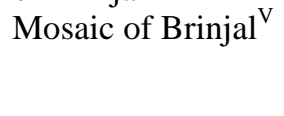 \\
\hline $\begin{array}{l}\text { Phomopsis blight of } \\
\text { Brinjal }^{\text {F }}\end{array}$ & $\begin{array}{l}\text { Cercospora leaf } \\
\text { spot of Chili }^{\text {F }}\end{array}$ & $\begin{array}{l}\text { Cercospora leaf } \\
\text { spot of Chili }{ }^{\mathrm{F}}\end{array}$ & $\begin{array}{l}\text { Taro leaf blight } \\
\text { of Colocasia leaf } \\
\text { B }\end{array}$ & $\begin{array}{l}\text { Cercospora leaf } \\
\text { spot of Chili }^{\mathrm{F}}\end{array}$ \\
\hline $\begin{array}{l}\text { Cercospora leaf spot } \\
\text { and Fruit rot of Chilli }{ }^{\mathrm{F}}\end{array}$ & $\begin{array}{l}\text { Bacterial wilt of } \\
\text { Cowpea }^{B}\end{array}$ & $\underset{\mathrm{V}}{\text { Mosaic of Chili }}$ & $\begin{array}{l}\text { Bacterial leaf } \\
\text { blight of } \\
\text { Cowpea }\end{array}$ & $\begin{array}{l}\text { Leaf curl and } \\
\text { Mosaic of Chili v }\end{array}$ \\
\hline Mosaic of Chili ${ }^{\mathrm{V}}$ & $\begin{array}{l}\text { Anthracnose of } \\
\text { Cowpea }^{\mathrm{F}}\end{array}$ & $\begin{array}{l}\text { Taro leaf blight } \\
\text { of Colocasia leaf } \\
\text { B }\end{array}$ & $\begin{array}{l}\text { Mosaic of } \\
\text { Cowpea }\end{array}$ & $\begin{array}{l}\text { Bacterial blight and } \\
\text { Bacterial wilt of } \\
\text { Cowpea }{ }^{B}\end{array}$ \\
\hline $\begin{array}{l}\text { Bacterial wilt of } \\
\text { Cowpea }\end{array}$ & $\begin{array}{l}\text { Late blight of } \\
\text { Tomato }\end{array}$ & $\begin{array}{l}\text { Halo blight of } \\
\text { Cowpea }\end{array}$ & $\begin{array}{l}\text { Anthracnose of } \\
\text { Okra }{ }^{\mathrm{F}}\end{array}$ & Rust of Cowpea ${ }^{F}$ \\
\hline Anthracnose of Cowpea & $\begin{array}{l}\text { Bacterial wilt of } \\
\text { Cucurbits }{ }^{B}\end{array}$ & $\begin{array}{l}\text { Anthracnose of } \\
\text { Cowpea } F\end{array}$ & $\begin{array}{l}\text { Bacterial wilt of } \\
\text { Cucurbits }{ }^{B}\end{array}$ & $\begin{array}{l}\text { Early blight of } \\
\text { Okra F }\end{array}$ \\
\hline Mosaic of Cowpea ${ }^{\mathrm{V}}$ & $\begin{array}{l}\text { Alternaria leaf } \\
\text { spot, Downy } \\
\text { mildew and } \\
\text { Gummy stem } \\
\text { blight of Cucurbits } \\
\text { F }\end{array}$ & $\begin{array}{l}\text { Mosaic of } \\
\text { Cowpea }\end{array}$ & $\begin{array}{l}\text { Gummy stem } \\
\text { blight of } \\
\text { Cucurbits }\end{array}$ & Mosaic of Okra ${ }^{\mathrm{V}}$ \\
\hline $\begin{array}{l}\text { Choanephora fruit rot } \\
\text { and Early blight of } \\
\text { Okra F }\end{array}$ & $\begin{array}{l}\text { Mosaic of } \\
\text { Cucurbits }\end{array}$ & $\begin{array}{l}\text { Cercospora leaf } \\
\text { spot of Okra }\end{array}$ & $\begin{array}{l}\text { Mosaic of } \\
\text { Cucurbits }\end{array}$ & $\begin{array}{l}\text { Early blight of } \\
\text { Tomato }\end{array}$ \\
\hline $\begin{array}{l}\text { Bacterial spot of } \\
\text { Tomato }\end{array}$ & & $\underset{\mathrm{V}}{\text { Mosaic of Okra }}$ & & $\begin{array}{l}\text { Bacterial wilt of } \\
\text { Cucurbits }{ }^{B}\end{array}$ \\
\hline Late blight of Tomato $^{\mathrm{F}}$ & & $\begin{array}{l}\text { Bacterial wilt of } \\
\text { Cucurbits }{ }^{B}\end{array}$ & & $\begin{array}{l}\text { Downy mildew and } \\
\text { Gummy stem }\end{array}$ \\
\hline
\end{tabular}


Journal of Agriculture and Natural Resources (2019) 2(1): 60-74

ISSN: 2661-6270 (Print), ISSN: 2661-6289 (Online)

DOI: https://doi.org/10.3126/janr.v2i1.26043

Powdery mildew,

Downy mildew and

Gummy stem blight of

Cucurbits ${ }^{\mathrm{F}}$

Mosaic of Cucurbits $\mathrm{V}$
Alternaria leaf

spot, Gummy

stem blight and

Downy mildew

of Cucurbits ${ }^{\mathrm{F}}$

Mosaic of

Cucurbits $\mathrm{V}$
$\underset{\mathrm{F}}{\text { blight of Cucurbits }}$

Mosaic of

Cucurbits ${ }^{\mathrm{V}}$

Note: ${ }^{\text {B - Bacterial disease, }}{ }^{\mathrm{F}-}$ - Fungal disease, ${ }^{\mathrm{V}}$ - Viral disease, n-sample size, ward no1: Satrasayaphant, Baradiphant and Dumridanda, ward no2: Yeklephant, Markichowk and Pateni, Ward no3: Gaadapani, Ward no 4: Saakhar Ward no 5: Ghummaune

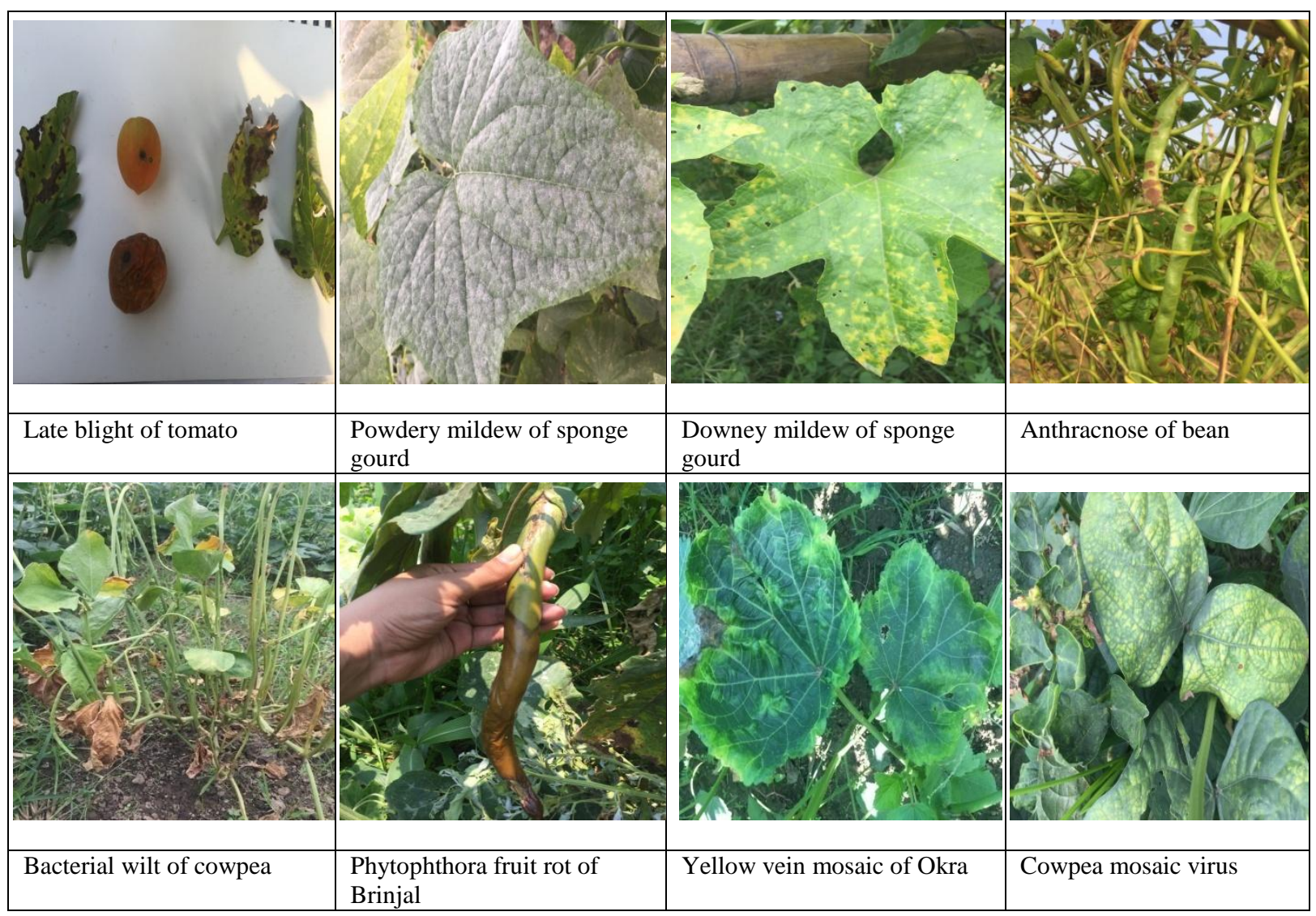

Plate 1: Photographs illustrated symptoms of major diseases on vegetables noticed in farmers field of 5 wards of Aanbukhaireni rural municipality of Tanahu district, Nepal during spring season of 2019.

Table 2: Disease incidence and severity of vegetable diseases in farmers field of 5 wards of Aanbukhaireni rural municipality of Tanahu district, Nepal during spring season of 2019

\begin{tabular}{ccccccc}
\hline Surveyed ward & \multicolumn{3}{c}{ Disease incidence (DI\%) } & \multicolumn{3}{c}{ Percent Disease Index (PDI\%) } \\
\hline & Mean & SD & SE \pm & Mean & SD & SE \pm \\
\hline Ward no 1 $(\mathrm{n}=15)$ & 51.23 & 13.57 & 3.50 & 40.00 & 6.41 & 1.66 \\
Ward no 2 $(\mathrm{n}=18)$ & 70.00 & 25.13 & 5.92 & 48.00 & 12.04 & 2.84 \\
Ward no 3 $(\mathrm{n}=21)$ & 52.82 & 16.47 & 3.59 & 42.48 & 7.85 & 1.71 \\
Ward no 4 $(\mathrm{n}=14)$ & 45.20 & 17.09 & 4.57 & 37.71 & 6.60 & 1.44 \\
Ward no 5 $(\mathrm{n}=19)$ & 49.55 & 15.22 & 3.49 & 38.32 & 6.84 & 1.57 \\
\hline
\end{tabular}

Note: SD- Standard deviation, SE \pm - Standard error, n-sample size, ward no1: Satrasayaphant, Baradiphant and

Dumridanda, ward no2: Yeklephant, Markichowk and Pateni, Ward no3: Gaadapani, Ward no 4: Saakhar Ward no 5: Ghummaune 
Journal of Agriculture and Natural Resources (2019) 2(1): 60-74

ISSN: 2661-6270 (Print), ISSN: 2661-6289 (Online)

DOI: https://doi.org/10.3126/janr.v2i1.26043

The higher disease incidence $(70 \%)$ and severity $(48 \%)$ in vegetables were recorded in ward no 2 followed by ward no 3 with incidence of $53 \%$ and severity $42.48 \%$. The lower incidence $(45.2 \%)$ and severity (37.71\%) were found in ward no 4 (Table 2 ).

The findings regarding to the vegetable diseases of this survey are in line with many earlier research reports. Bose and Som (1986) reported that early blight of tomato caused by Alternaria solani was first recorded in 1882 in New Jersey, USA. Bacterial spot of tomato and pepper plants caused by Xanthomonas axonopodis pv. vesicatoria has been observed causing significant losses, estimated of about 10-20\% per year and is observed in the area where Capsicum annuum and Solanum lycopersicum L. are cultivated. The pathogen causing bacterial spot have been a subject to many studies and reclassifications since the last 20 years (Stoyanova et al., 2014). Powdery mildew caused byErysiphe cichoracearum is the world's most frequently encountered plant pathogenic fungi, infecting leaves, stems, flowers and fruits of nearly 10,000 species of angiosperms (Glawe, 2008) including many vegetable crops (Dixon, 1978). Downy mildew, caused by Pseudoperonospora cubensis in cucurbits was first recorded from Cuba in 1868 (Berkeley \& Curtis, 1868). It was then reported from Japan after 20 years (Kurosawa, 1927). It has since spread to almost all countries in which cucurbits are grown commercially. Numerous soil-borne fungi belonging to Pythium and Phytophthora, and some seed-borne fungi, have been reported to cause damping-off on a large number of crops. These pathogens can be spread via non-anthropic and anthropic activities, including water run-off through irrigation or rain (Zappia et al., 2014), soil contamination by improperly sanitized tools, introduction of infected plants, improperly sanitized greenhouse, and the use of contaminated irrigation water ( Papavizas \& Davey, 1961; Duniway, 1983; Schmitthenner \& Canaday,1983; Huang \& Kuhlman 1990; Starkey \& Enebak 2012). The symptoms of cowpea aphid borne mosaic polyvirus (CABMV) was recorded during 1989-1990 at Rampur which was transmitted by both aphids and sap inoculations (Dahal \& Albrechtsen, 1996 ).Cucumber mosaic virus (CMV), Chili veinal mottle polyvirus (CVMV) and Tomato yellow leaf curl gemini virus (TYLCV) were the most common viruses in chili identified in Nepal (Joshi \& Shrestha, 2001).

\section{Diseases of fruits}

The major fruits found in the surveyed area were banana, papaya, grapes, mango, litchi, peach, guava, lemon, mandarin orange etc.

Table 3: Major fruit diseases of 2 wards of Aanbukhaireni rural municipality of Tanahu district, Nepal during spring season of 2019

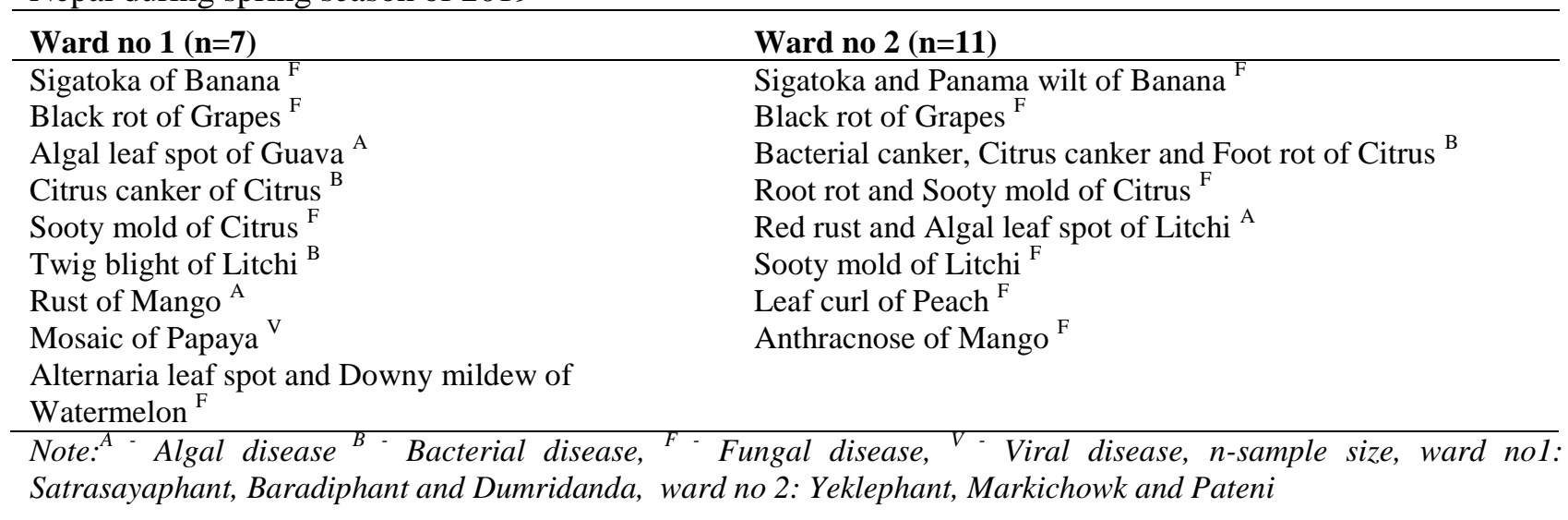


Journal of Agriculture and Natural Resources (2019) 2(1): 60-74

ISSN: 2661-6270 (Print), ISSN: 2661-6289 (Online)

DOI: https://doi.org/10.3126/janr.v2i1.26043

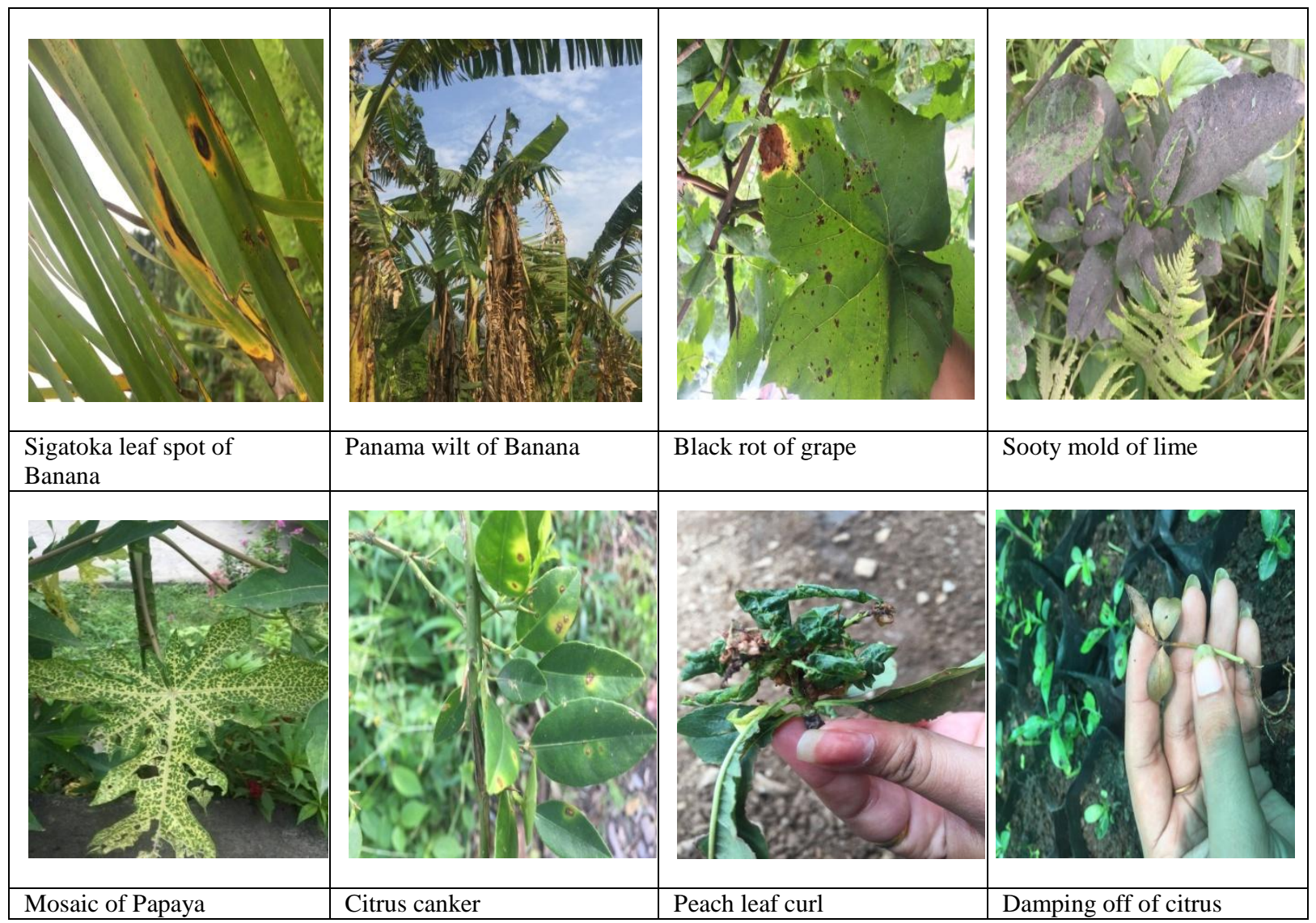

Plate 2: Photographs illustrated symptoms of major fruit disease noticed in farmers field of 2 wards of Aanbukhaireni rural municipality of Tanahu district, Nepal during spring season of 2019.

Table 4: Disease incidence and severity of fruit diseases in farmers field of 2 wards of Aanbukhaireni rural municipality of Tanahu district, Nepal during spring season of 2019

\begin{tabular}{ccccccc}
\hline Surveyed ward & \multicolumn{2}{c}{ Disease incidence $(\mathbf{D I \% )}$} & \multicolumn{2}{c}{ Percent Disease Index (PDI\%) } \\
\hline & Mean & SD & SE \pm & Mean & SD & SE \pm \\
\hline Ward no 1 $(\mathrm{n}=7)$ & 70.24 & 17.25 & 6.52 & 51.27 & 7.90 & 2.99 \\
Ward no 2 $(\mathrm{n}=11)$ & 66.79 & 27.99 & 8.44 & 45.14 & 21.60 & 6.51
\end{tabular}

Note: SD-Standard deviation, SE \pm - Standard error, n-sample size, ward nol: Satrasayaphant, Baradiphant and Dumridanda, ward no2: Yeklephant, Markichowk and Pateni,

Diseases like sigatoka leaf spot, panama wilt, black rot, algal leaf spot, canker, root rot, foot rot, sooty mold, red rust, anthracnose, rust, mosaic, alternaria leaf spot, downey mildew and leaf curl were the major diseases noticed during survey period (Table 3, Plate 2).

The higher fruit disease incidence $(70.24 \%)$ and severity $(51.27 \%)$ in ward no 1 followed by ward no 2 with disease incidence and severity of $66.79 \%$ and $45.14 \%$ respectively were recorded (Table 4). The finding of the survey is well supported by Coates \& Johnson (1997) who reported that the quality and quantity of the fruits produced is mainly affected by the many diseases. It becomes noticeable during pre- harvest stage and if no any precautions are taken during the picking, storing, packaging and transporting processes, the situation 
Journal of Agriculture and Natural Resources (2019) 2(1): 60-74

ISSN: 2661-6270 (Print), ISSN: 2661-6289 (Online)

DOI: https://doi.org/10.3126/janr.v2i1.26043

becomes much worst. According to the infection started, they are named as 'quiescent' or 'latent' infections, where the pathogen infects the host commonly at pre-harvest. During ripening process, intense physiological changes of the fruit may activate the quiescent infections (Coates \& Johnson, 1997). Most of the fungi causing fruit diseases belong to the phylum Ascomycota in which the asexual stage of fungus (anamorph) is commonly found to be the causal agent of fruit rot. A number of diseases such as brown rot in citrus caused by Phytophthora citrophthora and P. parasitica are due to the main fruit rot pathogens in Oomycota of genera Phytophthora. Rhizophus and Mucor in Zygomycota are the important genera of fruit rot pathogens and the common pathogen that caused wound in wide range of fruit and vegetables was found to be Rhizopus stolonifer (Snowden, 1990; Coateset al., 1995; Johnson \& Coates, 2009). The production of banana is the important earning source for most exporting countries including China, Philippines, Brazil, Ecuador, Indonesia, Costa Rica, Mexico, Thailand, Colombia (Nathet al., 2015), Sri Lanka (Anthonyet al., 2004; Indrakeerthi \& Adikaram, 2011), Windward Islands, Eastern Carribbean (Krauss \&Johanson, 2000), Egypt (Abd- Allaet al., 2014), Australia (Nelson, 2008), Africa and Latin America (Lassoiset al., 2010). Fungal species isolated from finger rot disease of banana are Lasidioplodia theobromae, Musicillium theobromae, Alternaria triticina, Cladosporium oxysporum, Acremoniums spp., Culvularia sp., Bipolaris sp. and Eupenicillium sp.mostly affect the fingers of banana fruits due to the their first infection on the crown part of banana fruit, Aspergillus sp. and Penicillium sp.may cause secondary infection to the banana fruits (Sepiah et al., 1990; Anthony et al., 2004; Faber et al., 2007; Nelson, 2008; Ewane et al., 2012; AbdAlla et al., 2014; Twumasiet al., 2014). The research report is also in line with the many earlier research findings of fruit diseases. Powdery mildew of mango caused by OidiummangiferaeBarthet is reported in the countries like Burma, Bangladesh, Nepal, Pakistan, Sri Lanka, Israel, Lebanan (Asia); New South Wales, Queensland and New Calodonia (Australia); Congo, Egypt, Ethiopia, Kenya, Malawi, Mozambique, Mauritius, Reunion, Tanzania, Zambia, Zimbabwe, Zaire, South Africa, (Africa); California, Florida (USA); Mexico, Jamaica, Costa Rica, Guatemala (Central America): Brazil, Venezuela, Colombia, Peru (SoUUl America) (Prakash, 1988).Anthracnose caused by Colletotrichum gloeosporioides is reported from India, USA, Cuba, Philippines, British Guiana, Dominican Republic, Mauritius, Fiji, Sierra Leone, Brazil, Columbia, Guatemala, Mozambique, Dutch East Indies, Portugal, Pakistan, Trinidad, Peru, French Guiana, Taiwan, Uganda, Jamaica, Sri Lanka, Congo, Morocco, South Africa ( Prakash \& Srivastava, 1987). Mango malformation was first introduced by Maries from Darbhanga, Bihar in 1891. The disease is mainly restricted to northern India, where over $50 \%$ of the trees are affected. Other countries like Egypt, South Africa, Israel, Central America, Mexico, Florida (U.S.A.), Sudan, Cuba, Brazil, Australia, Bangladesh, Pakistan and United Arab Emirates has also been infected by mango malformation (Kumar \&Beniwal, 1992; Kumaret al., 1993).Die back of mango is caused by Botryodiplodia theobromae Pat. (Prakash \&Raoof, 1989; Rathet al., 1978). Twig blight of mango was found associated with Botryosphaeria ribis in U.S.A. (California) (Prakash \& Eckert, 1992). Sooty mould in mango is caused by several fungi such as Meliola mangiferae Earle, Capnodium mangiferae and, Capnodiumramosum (Ke.) and Tripospermum acerinum (Syd.) Speg. (Das \&Mohanty, 1972). Authors found that the disease is also caused by Microxyphium columnatum, Leptoxyphium fumago andTripospermum myrti (Prakash, 1988). 
Journal of Agriculture and Natural Resources (2019) 2(1): 60-74

ISSN: 2661-6270 (Print), ISSN: 2661-6289 (Online)

DOI: https://doi.org/10.3126/janr.v2i1.26043

\section{Fungal pathogens isolated from the disease sample}

The microscopic images of the fungal pathogens isolated from the diseased samples collected from different wards of the surveyed areas were shown in the plate3.

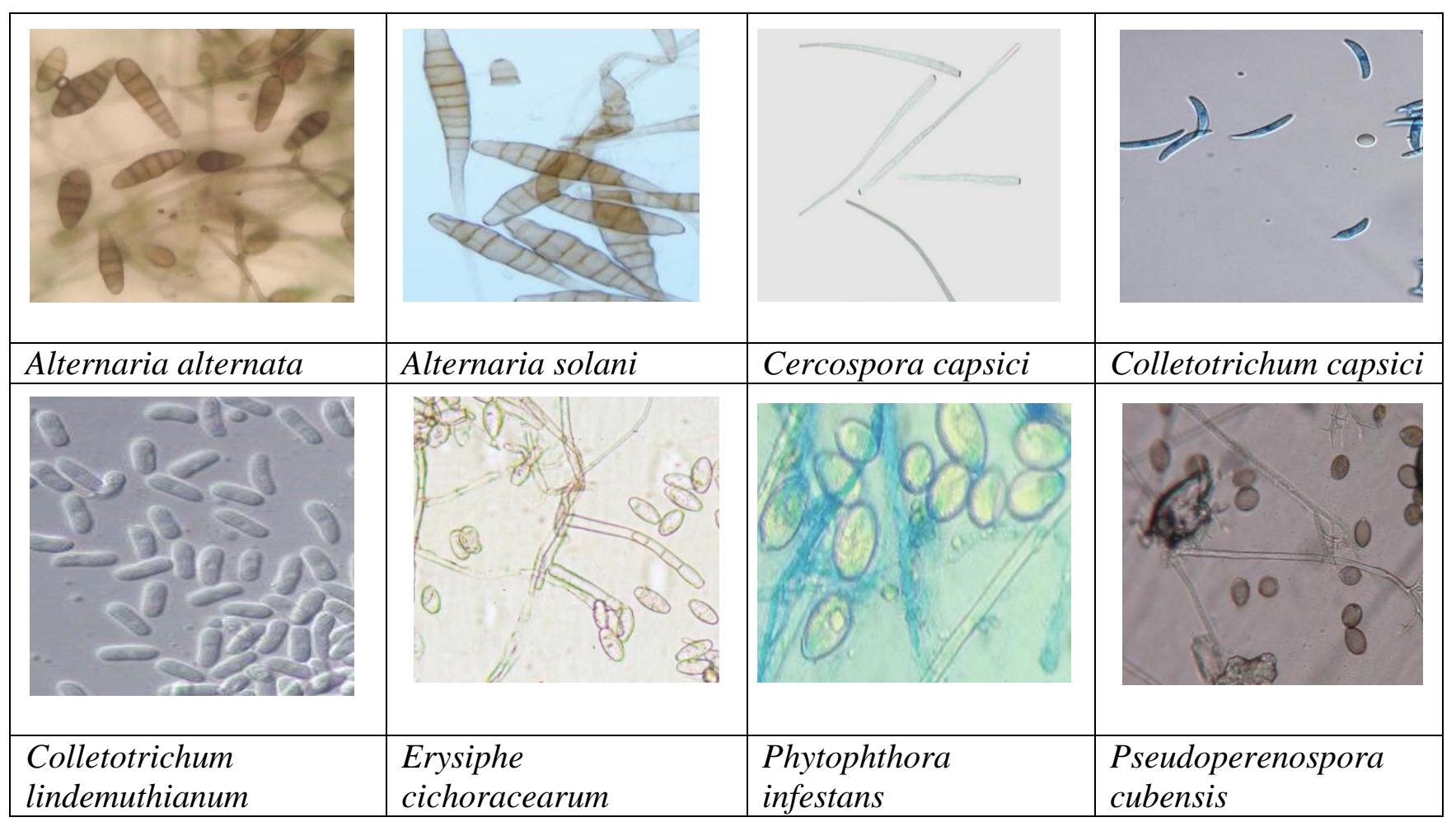

Plate 3: Photographs illustrated microscopic images of the fungal pathogens isolated from the diseased samples collected from different wards of the surveyed areas during spring season of 2019.

\section{Socioeconomic factors}

Education: The education level of the farmers from surveyed area wasmostly basic and secondary level only. Among the farmers were surveyed, some of them follow informal education and also significant number of farmers were illiterate. The farmers' educational level has a major affect in improving their total production and per capita income, by having majority control over diseases and insect pests.

Occupation: Agriculture is the main occupation in the surveyed wards. However, because of the migration of youth peoples towards abroad and gulf countries for job and other purposes, only elder peoples, women and children were found in the villages and involved in the farming. Among others, one of the reasons behind the rural migration is the distraction of youths from agriculture as the image of the farmer is less than attractive.

Age: Data showed that the average age of farmers in surveyed area already exceeds 50 and there is an exodus of rural youths to the cities, creating a shortage of manpower to even carry the sick to hospital or dead bodies to the ghats. There are only women, children and elderly people in many villages whereas the youth are either in the towns or in foreign countries in 
Journal of Agriculture and Natural Resources (2019) 2(1): 60-74

ISSN: 2661-6270 (Print), ISSN: 2661-6289 (Online)

DOI: https://doi.org/10.3126/janr.v2i1.26043

search of employment and opportunities for study. Among others, one of the reasons behind the rural exodus is the distraction of youths from agriculture as the image of the farmer is less than attractive.

Land holding: Most of the farmers have small land holdings (5-10 ropani) in the surveyed area. Large proportion of farm households occupy small proportion of total farm land, small proportion of farms occupies a large proportion of land. Low productivity is also the reason for poverty. Rapid agricultural growth is essential for rapid reduction in incidence of poverty.

Agricultural inputs: The use of agricultural inputs like fertilizers and chemicals play an important role to maximize the yield of crops as well as the attraction of farmers towards farming. Most of the farmers interviewed described that fertilizers and chemicals are not easily available in the market and if available, they are very expensive that cannot be afforded by them. Increasing investment in the small farmer for integrated rural development, orientation, training and education for the youth in agriculture, ensuring access and control of the youth on land, market, credit, seeds, pesticides, fertilizers and other resources are necessary to change the image of farming from one that is dirty and difficult to one that is decent and highly income-generating. Furthermore, professionalism, mechanization and commercialization of production can change the image of farming. Subsidies, insurance, grants and creation of a conducive environment are equally important to attract the new and young generation to this important sector.

\section{CONCLUSION}

During the survey, among all the diseases occurred on vegetables and fruits, some were due to fungal, some were caused by bacteria and viral infections and a few were affected by physiological disorders and algal infections too. These diseases were identified based on their symptoms occurred throughout the plant and the pathogen identifications were carried out in the Pathology laboratory of National Maize Research Program, Rampur, Chitwan .The major diseases of vegetables noticed were early blight, late blight, cercospora leaf spot, powdery mildew, downey mildew, fruit rot, bacterial wilt, bacterial spot, leaf curl and mosaic. In case of fruits, sigatoka leaf spot, panama wilt, black rot, algal leaf spot, canker, root rot, foot rot, sooty mold, red rust, anthracnose, rust, mosaic, alternaria leaf spot, downey mildew and leaf curl were the major diseases. This study explored the major diseases of vegetables and fruits of terai and inner terai region of Nepal and applying control measure, looking for the best possible solutions.

\section{ACKNOWLEDGEMENTS}

The authors are grateful to all concerned scientists, officers and technicians from the NARC stations and line agencies supported during survey period. Thanks are extended to the members of cooperatives, representatives of NGOs and farmers for continuous support to carry out the survey and providing secondary information and facilities to prepare this manuscript. 
Journal of Agriculture and Natural Resources (2019) 2(1): 60-74

ISSN: 2661-6270 (Print), ISSN: 2661-6289 (Online)

DOI: https://doi.org/10.3126/janr.v2i1.26043

\section{Author Contributions}

S.S. designed the survey, analysed data and wrote the paper; S.K. helped during conducting the survey and recording observations. S.N. helped during manuscript preparation.

\section{Conflicts of Interest}

The authors declare that there is no conflict of interest regarding the publication of this paper.

\section{REFERENCES}

Abd-Alla, M. A., El-Gamal, N. G., El-Mongy, N. S., \& Abdel-Kader, M. M. (2014). Postharvest treatments for controlling crown rot disease of Williams banana fruits (Musa acuminata L.) in Egypt. Plant Pathology and Quarantine, 4(1), 1-12.

Abewoy, D. (2018) Review on Impacts of Climate Change on Vegetable Production and its Management Practices. Advances in Crop Science and Technology, 6, 330. doi:10.4172/2329-8863.1000330

Afroza, B., Wani, K.P., Khan, S.H., Jabeen, N., \& Hussain, K. (2010). Various technological interventions to meet vegetable production challenges in view of climate change. Asian J Hort, 5, 523-529.

Aneja, K.R. (2004). Experiment in microbiology, plant pathology and biotechnology. 4th Ed, New International (P) Limited Publisher, India, 121-128.

Anthony, S., Abeywickrama, K., Dayananda, R., Wijeratnam, S. W., \& Arambewala, L. (2004). Fungal pathogens associated with banana fruit in Sri Lanka and their treatment with essential oils. Mycopathologia, 157, 91-97.

Berkeley, M.S., \& Curtis, A. (1868). Peronosporacubensis. J. Linn. Soc. Bot., 10, 363.

Bose, T.K. \& SOM, M.G. (1986). Vegetable Crops in India. Nayaprakash Publishing, Calcutta. 773p.

Cerda, R., Avelino, J., Gary, C., Tixier, P., Lechevallier, E., \& Allinne, C. (2017). Primary and secondary yield losses caused by pests and diseases: Assessment and modeling in coffee. PLoS ONE, 12(1), 1-17. https://doi.org/10.1371/journal.pone.0169133.

Choudhary B.R., Fageria, M.S. \& Dhaker, R.S. (2009). A text book on production technology of vegetables, Second Edition, Kalayanic Publishers, New Delhi. International, 43, 1745-1765.

Coates, L., \& Johnson, G. (1997). Postharvest diseases of fruit and vegetables. Plant Pathogens and Plant Diseases, 533-548.

Coates, L., Cooke, A., Persley, D., Beattie, B. B., Wade, N. L., \& Ridgeway, R. (1995) Postharvest diseases of horticultural produce. Tropical fruit. Queensland: DPI Publishing.

Dahal, G., \& Albrechtsen, S.E. (1996). Some studies on cowpea aphid-borne mosaic and pea seed-borne mosaic potyviruses in Nepal. International Journal of Pest Management, 42(4), 337-344. DOI: 10.1080/09670879609372018

Das, S.R \& Mohanty, N.N. (1972). A note on some fungi from Orissa. CurroSci, 41, 430.

Dhami, N. B., Kim, S. K., Paudel, A., Shrestha, J., \& Rijal, T. R. (2015). A review on threat of gray leaf spot disease of maize in Asia. Journal of Maize Research and Development, 1(1), 71-85.

Dixon, G.R. (1978). Powdery mildews of vegetable and allied crops. In: Spencer DM,ed. The Powdery Mildews. NewYork,USA: Academic Press, 495-524. 
Journal of Agriculture and Natural Resources (2019) 2(1): 60-74

ISSN: 2661-6270 (Print), ISSN: 2661-6289 (Online)

DOI: https://doi.org/10.3126/janr.v2i1.26043

Duniway, J.M. (1983) Role of physical factors in the develop-ment of Phytophthora diseases. In: Erwin DC, Bartnicki-Garcia S, Tsao PH (eds) Phytophthora its Biol. Taxon. Ecol. Pathol. American Phytopathological Society, St. Paul, Minn, USA, pp 175-187

Ewané, C. A., Lepoivre, P., de Lapeyre de Bellaire, L., \& Lassois, L. (2012). Involvement of phenolic compounds in the susceptibility of bananas to crown rot. A review. Biotechnol. Agron. Sci. Environ, 16(3), 393-404.

Faber, G. A., Bender, G. S., \& Ohr, H. D. (2007). UC IPM pest management guidelines. Diseases (pp. 3436) UC ANR publication.

FAO. (2000). The state of food insecurity in the world (SOFI). Rome, Italy: FAO, UN. www.fao.org/FOCUS/E/SOFI00/sofi001-e.htm

Glawe, D.A. (2008). The powdery mildews: a review of the world's most familiar (yet poorly known) plant pathogens. Annual Review of Phytopathology, 46, 27-51.

Huang, J.W., \& Kuhlman, E.G. (1990). Fungi associated with damping-off of slash pine seedlings in Georgia. Plant Disease,74,27-30.

Indrakeerthi, S. R. P., \& Adikaram, N. K. B. (2011). Control of crown rot of banana using Carica papaya latex. J. Natn. Sci. Foundation Sri Lanka, 39(2), 155-162.

Jarvis, D.I., Fadda, C., De Santis, P., \& Thompson, J. (2011). Damage, diversity and genetic vulnerability: The role of crop genetic diversity in the agricultural production system to reduce pest and disease damage, Proceedings of an International Symposium 15-17 February, 2011, Rabat, Morocco. Bioversity International, Rome Italy.

Johnson, G. I., \& Coates, L. (2009). Postharvest diseases of fruit and vegetables. In T. Cooke, D. Persley\& S. House (Eds.), Diseases of fruit crop in Australia (pp. 533-548). State of Queensland, Australia: CSIRO Publishing.

Joshi, S., \& Shrestha, S.K. (2001). Integrated disease and pest management leaf curl and other viruses of tomato and pepper. Proceedings of the South Asia Vegetable Research Network (SAVERNET II) Final Workshop. 3-8 June 2001. Bangkok. Thailand. Asian Vegetable Research and Development Center, Shanhua, Tainan, Taiwan.

Krauss, U., \& Johanson, A. (2000). Recent advances in the control of crown rot of banana in the Windward Islands. Crop Protection, 19(2), 151-160.

Kumar, J. \& Beniwal, S.P.S. (1992). Mango malformation. In: Plant Diseases of International Importance (Eds. J. Kumar, H.S. Chaube, U.S. Singh, A.N. Mukhopadhyay) 13,357-398. New York, Prentice Hall, 456 pp.

Kumar, J., Singh, U.S. \& Beniwal, S.P.S. (1993). Mango malformation: One hundred years of research. Ann. Rev. Phytopathol., 31, 217-232.

Kumar, S., \& Kaur, R. (2015). Plant Disease Detection using Image Processing- A Review, International Journal of Computer Applications, 124(16), 0975 - 8887.

Kurosawa, E. (1927). Studies on Plasmoparacubensis. J. Nat. Hist. Soc. Formosa, 17, 1-18.

Lassois, L., Frettinger, P., de Lapeyre de Bellaire, L., Lepoivre, P., \& Jijakli, H. (2010). Identification of genes involved in the response of banana to crown rot disease. The American Phytopathological Society, 24(1), 143-153. doi:10.1094/MPMI-01-10-0020

Manandhar, H.K., Timila, R.D., Sharma, S., Joshi, S., Manandhar, S., Gurung, S.B., Sthapit, S., Palikhey, E., Pandey, A., Joshi, B.K., Manandhar, G., Gauchan, D., Jarvis, D.I. \&Sthapit, B.R. (2016). A field guide for identification and scoring methods of diseases in the mountain crops of Nepal. NARC, DoA, LI-BIRD and Bioversity International, Nepal.

MOALD. (2018). Statistical Information in Nepalese Agriculture. Ministry of Agriculture 
Journal of Agriculture and Natural Resources (2019) 2(1): 60-74

ISSN: 2661-6270 (Print), ISSN: 2661-6289 (Online)

DOI: https://doi.org/10.3126/janr.v2i1.26043

and Livestock Development, Kathmandu, Nepal.

Nath, K., Solanky, K. U., \& Bala, M. (2015). Management of banana (Musa paradisiaca L) fruit rot disease using fungicides. Journal of Plant Pathology and Microbiology, 6(8), $1-7$.

Nelson, S. (2008). Postharvest rots of banana. College of Tropical Agriculture and Human Resources, $P D-54,1-4$.

Papavizas, C.G., \& Davey, C.B. (1961). Saprophytic behavior of Rhizoctonia in soil. Phytopathology, 51, 693-699.

Prakash, Om \& Srivastava, K.C. (1987). Mango diseases and their management - A World review. Today and Tommorow's Printers and Publishers, New Delhi. P. 180.

Prakash, Om. (1988). Sooty mould disease of mango and its control. Int. J. Trop. Plant Diseases, 9, 277-280.

Prakash, Om., \& Eckert, J.W. (1992). Twig die-back disease of mango (Mangifera indica) (Abs.) Proc. 4th Int. Mango Symposium, Florida (USA) .

Prakash, Om., \& Raoof, M.A. (1989). Die back disease of mango (Mangifera indica), its distribution, incidence, cause and management. Fitopatol, Bras, 14, 207-215.

Rath, G.C, Swain, N.C and Mohanan, M.K. (1978). A note on die back ofmango in Orissa. Indian Phytopath, 31, 384-386.

Schmitthenner, A.F., \& Canaday, C.H. (1983). Role of chemical factors in de- velopment of Phytophthora diseases. In: Erwin DC, Bartnicki- Garcia S, Tsao PH (eds) Phytoplithora its Biol. Taxon. Ecol. Pathol. American Phytopathological Society, St. Paul, pp 175-187.

Sepiah, M., Acedo, A.L., Sabari, S.D., Ilag, L.L., \& Kuthubutheen, A.J. (1990). Post-harvest physiology of banana. Banana Fruit Development- Post-Harvest Physiology, Handling and Marketing in ASEAN, ASEAN Food, Handling Bureau, Malaysia., A. Hassan. Er.B. Pantatico, ed. 104-111.

Shrestha, J., Subedi, S., Timsina, K.P., Gairhe, S. Kandel, M., \& Subedi, M. (2019).Maize Research. New India Publishing Agency (NIPA), New Delhi-34, India.

Snowden, A.L. (1990). A colour atlas of post-harvest diseases and disorders of fruits and vegetables. Wolfe Scientific, 1, 302.

Starkey, T., \& Enebak, S.A. (2012). Rhizoctonia blight of southern pines. In: Cram MM, Frank MS, Mallams KM (eds) For. Nurs. Pests. USDA Forest Service. Agriculture Handbook, Washington DC, pp 63-65.

Stoyanova, M., Vancheva, T., Moncheva P., \& Bogatzevska, N. (2014). Differentiation of Xanthomonas spp. Causing Bacterial Spot in Bulgaria Based on Biolog System. International Journal of Microbiology, 495476, 7.

Tirado, M.C., Clarke, R., Jaykus, L.A., McQuattersGollop, A., \& Frank, J.M. (2010). Climate change and food safety: A review. Food Research,43, 1745-1765.

Twumasi, P., Ohene-Mensah, G., \& Moses, E. (2014). The rot fungus Botryodiplodiatheobromae strains cross infect cocoa, mango, banana and yam with significant tissue damage and economic losses. African Journal of Agricultural Research, 9(6), 613-619. doi:10.5897/AJAR2013.7528.

Wheeler, B.E.J. 1969. An introduction to plant diseases. John Wiley and Sons. Ltd. London. UK.

Zappia, R.E., Huberli, D., Hardy, G.E.S.J., \& Bayliss, KL. (2014). Fungi and oomycetes in open irrigation systems: knowledge gaps and biosecurity implications. Plant Pathol ,63,961-972. doi:10.1111/ppa.12223 